\title{
The Position of Islamic Missionary on The Mechanisms of Despotism in The Emergence of The Islamic Nation
}

Moustafa Hassan Mohamed El Khayat, Mohammed Muneer'deen Olodo AIShafi'i, Muhammad Hedayatul Islam

To Link this Article: http://dx.doi.org/10.6007/IJARBSS/v11-i2/8665

DOI:10.6007/IJARBSS/v11-i2/8665

Received: 13 December 2020, Revised: 11 January 2021, Accepted: 24 January 2021

Published Online: 14 February 2021

In-Text Citation: (El Khayat et al., 2021)

To Cite this Article: El Khayat, M. H. M., AlShafi'i, M. M. O., Islam, M. H. (2021). The Position of Islamic Missionary on The Mechanisms of Despotism in The Emergence of The Islamic Nation. International Journal of Academic Research in Business and Social Sciences, 11(2), 221-231.

\section{Copyright: (C) 2021 The Author(s)}

Published by Human Resource Management Academic Research Society (www.hrmars.com)

This article is published under the Creative Commons Attribution (CC BY 4.0) license. Anyone may reproduce, distribute, translate and create derivative works of this article (for both commercial and non-commercial purposes), subject to full attribution to the original publication and authors. The full terms of this license may be seen at: http://creativecommons.org/licences/by/4.0/legalcode

\section{Vol. 11, No. 2, 2021, Pg. 221 - 231}

Full Terms \& Conditions of access and use can be found at http://hrmars.com/index.php/pages/detail/publication-ethics 


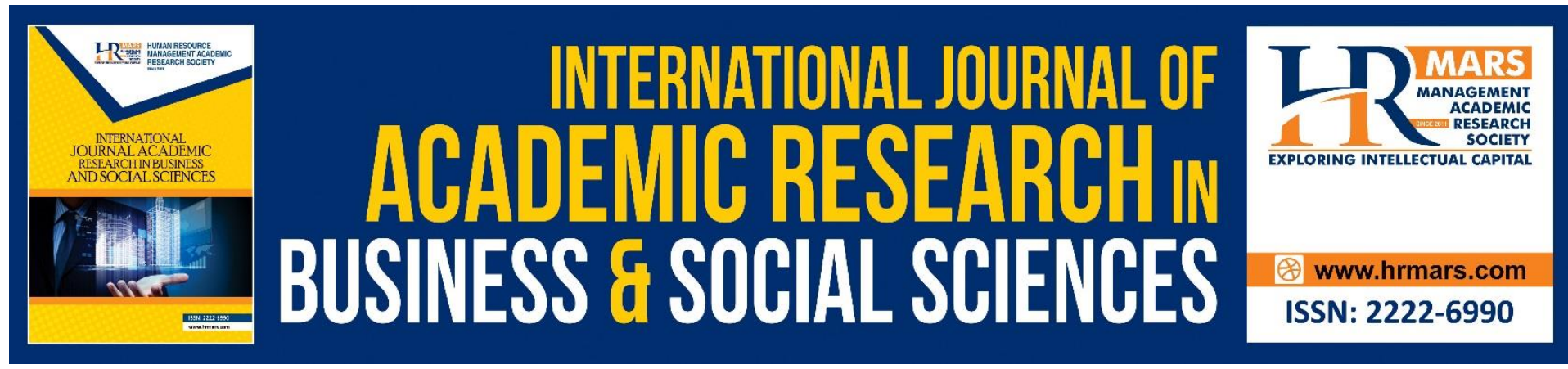

\title{
The Position of Islamic Missionary on The Mechanisms of Despotism in The Emergence of The Islamic Nation
}

\author{
Moustafa Hassan Mohamed El Khayat, Mohammed \\ Muneer'deen Olodo AIShafi'i, Muhammad Hedayatul Islam. \\ Faculty of Islamic Contemporary Studies (FKI), Universiti Sultan Zainal Abidin (UniSZA), \\ Terrengganu, Malaysia, \\ Email: moustafahassan@unisza.edu.my
}

\begin{abstract}
Islamic missionary had been accompanied by justice and freedom to ensure man's dignity. However, human despotism (tyranny) with its mechanism hampered that. The contemporary west has got rid of the tyranny to a great extent, which confirms with the nature of Islamic missionary in ensuring man's dignity. However, despotism has become a predominant trend in the whole Arab world. This is traced back with deep roots, to the era of Umayyad caliphate. This caliphate had given rise to despotic ruling systems with falsely gained false legality though disguising them with the mask of religion to form a sacred rule. Contemporary Arab regimes have found the emergence of the early Islamic nation to have mechanisms that meet their desires for tyranny. These mechanisms are far from the right ruling systems during the rule of Prophet Muhammad and the rightly guided caliphs. The problem of this study consists in the hypothesis of the existence of tyranny mechanisms traced back, with deep roots, to the early emergence of the state in the Arab world, which made non-Muslims accuse Islam of being despotic. Aims of the study: It aimed at Uncovering the roots and mechanisms of the emergence of despotism in the Arab world. Proving that Islam is innocent of despotism and Islamic missionary work plays a role in getting rid of it. Proving that Islam is not guilty of despotism and that Islamic missionary vocation is a call for the dignity of all people. The study uses descriptive analytical approach. And concludes that despotism in the Arab world is dated back, with historical roots, to the early formation of state or nation under the Umayyad and the Abbasids. That an Arab person accept the despotism and even seeks it if not existent. That the ruling systems of Arab nation cooperated to impose servility on its societies. The immigration of a lot of youths and scientists to the western world, looking forward to a decent life. Missionary work plays an important role in enlightening people about their rights in confronting despotism. Islamic missionary work is innocent of all accusations of despotism related to it. Religious beliefs had ensued upon political events, essentially aiming at empowerment of despots and tyrants. This study recommends the necessity of conducting contemporary missionary studies for uncovering the mechanisms of despotism which are renewable in our contemporary Arab world. The need for psychological missionary studies for combatting despotism in our societies. Setting up societal centres and international
\end{abstract}


conferences that make the society aware of the bad consequences of despotism, and that it is the cause of civilization backwardness of the Islamic and Arab nation and the immigration of a lot of geniuses abroad. Conducting studies that highlight the role of Islamic missionary vocation in achieving justice and human dignity for all. The need for conducting studies for refuting the illusions of secularists and orientalists that accuse Islam of despotism and tyranny.

Keywords: Missionary Vocation, Mechanisms, Despotism, Emergence, The Arab World

\section{Introduction}

The beginning of political life in Islam had been ideal, as prophet Muhammed (s.a.w) had used it to stabilize freedom, justice and equality among all people. Prophet Muhammed (s.a.w) came to a man and began to talk to him. Then, the man began to shiver with fear. So, the prophet said to the man: "Don't panic! For I am a lay man, not a monarch". Another citation is the hadith of Prophet Muhammed (s.a.w) saying: "People are as equal as the teeth of a comb". Idealism had extended through the rule of the two honourable rightly guided caliphs, Abu Bakr al-Siddiq and Umar Ibn al-Khattab, to reach the era of Uthman and Ali Ibn Abi Talib. Then the rightly guided caliphate transformed into an arbitrary monarchy that had originated despotism through specific mechanisms. These are the subject of our study that comprises two treatises. One is about the mechanism of the origination of tyranny in the Arab world, and the other tackles the stand of Islamic missionary vocation on the mechanism of the origination of tyranny. This is then followed by conclusion, results, and recommendations.

\section{The Mechanisms of Origination of Despotism(tyranny) in the Arab World}

The linguistic concept of (tyranny) and its use in the Quran. In al-Qamus al-Muhit, to tyrannize is "to exceed limits, be haugty, show excessive blasphemy (or disbelief), and overly commit sins and transgression. A tyrant is thus an unjust despot or a foolish haughty person (Abadi, n.d:1685). Ibn Shamil believes a tyrant is a foolish, proud, unjust person. In addition, Shamar also says "a tyrant is the one who is indifferent as to whatever he takes or seizes, this who grabs others, thing unjustly and by force and that who is never prevented by shame or fear (Ibn Manzour, n.d). According to Imam al-Tha'alibi, tyranny is a "misled evildoing and one's excessive use or abuse of anything". Zeidan explains tyranny as "One exceeding one's limits, that Allah had set for him in His Revelation and exceeding his status by which Allah had honoured him, which is his slavery to Allah and obedience to Him" (Zeidan, 1993:189-190).

Tyranny or despotism in the Quran has a denotation that includes all types of transgression, corruption, and haughtiness, all of which have traces in the Quran. Some examples in the qur'an are, but not limited to: "Nay, indeed man doeth exceed limits" (Surah al-'Alaq, 6); and "Go to pharoah as he did become a tyrant" (Surah Taha, 43). Tyranny is the most comprehensive term for all these meanings. It embraces all the denotations referring to pharaonic transgression, as tyranny (despotism) forces people to do the opposite of what they mentally accept.

A tyrant forces you to do only what is good for him, and to make your deeds compliant to his imposed belief. This notion is not included in the other partial or subsidiary terms, such as despotism, dictatorship, or totalitarianism. 'Tyranny' is the father to all other, it has an overall comprehensive meaning, while others have partial meanings (Imam, 1994: 54). 


\section{The Origin of Tyranny in The Islamic Dynasty}

The motive behind the rightly guided caliphate was a purely religious and tolerant one. Then it transformed into fanatic party spirit and fighting. Across time, the demonstration of Islamic Caliphate vanished, and only its name remains. The whole affair was purely a matter of monarchy. The instinct of loving ruling reached its extreme, using for its purposes vanquishing subjugation and floundering pursuit of greedy lusts and joys.

Then, occurred the dispute between 'Ali bin Abi Talib and Mu'awiyah Ibn Abi Sufyan. It was a disagreement between two regimes (systems) and philosophies of ruling.

One of them was based on idealism in ruling that rejected luxury and subjugating people for the interests of princes and subjugating people with humiliation. Thus, it was a struggle between the religious caliphate, represented in Ali bin Abi Talib, and the secular state, represented in Mu'awiyah Ibn Abi Sufyan (Al-Aqqad, 2012: 52-53).

Tyranny began with political intrigues and military coups, without legal reasons "and those were never expected" (Al-Fayumi, 2003: 131). Then Mu'awiyah declared openly the truth of his monarchy over the pulpit of Allah's messenger. He said: "I swear by God, I had not been nominated monarch out of your declared love for me or your pleasure with my succession to the rule. Rather, I had fought you hard with this sword of mine" (Safwat, 1996:182). Mu'awiyah always reiterated: "I am the first of all monarch". In this way, the Umayyad dynasty exterminated the seeds of democracy that had emerged under the rightly guided caliphs and stopped their growth. Then complete separation between reality and ideal took place (Imam, 1994: 167).

Mu'awiyah used the murder of Uthman as a pretext to justify his seizure of the caliphate. Mu'awiyah exploited with an extraordinary keenness, some of the prophet's companions and followers to stabilize his tyranny (Al-Nashar, 1977:302).

\section{The mechanisms of origination of tyranny for the sake of stabilizing monarchy in the Islamic Dynasty or state}

The mechanisms of vanquishing and defeating: This is due to the control of military force and staging coups against democracy in the contemporary Arab world. This started the day Mu'awiyah staged a coup against the caliph Ali bin Abi Talib, instead of paying him loyalty. This culture, in turn, has produced in our society an acceptability of the behaviour of vanquishing and subjugation, the pharaoh manners.

The Umayyad moved the nation from the rightly guided caliphate to despotic monarchy, through vanquishing and subjugation, and depending on ethnicity and tribalism (Ibn-Khaldun, n.d:75). Mu'awiyah knew that the Muslim community did not like him as a ruler and never rejoiced it. Moreover, he never fought them to make them perform prayer or fasting. For he knew they are abiding by that sincerely. Rather, his end in fighting them was as he said in his speech: "I swiped you violently with this sword of mine... and fought you to gain power over you. So, Allah bestowed his power on me, while you hated it" (Al-Zahabi, 1985:147-148).

The overpowering of the Umayyad was directed towards whomsoever opposed their heresy in monarchy, which is calling for belief in fatalism. So, they murdered Maibad Al-Gahni and Ghailan of Damascus, who was a pious follower of the prophet. This was not for a deviation in his belief. Rather, as the sheikh of Al-Azhar put it, "they killed him on account of a political disagreement. May God's curse be on politics!" (Mahmoud, 1955:202).

Thus, the method of ruling among the Umayyad was based on subjugation, and not on election or consultation. For in a speech by Abdul Malik Ibn Marwan on the pulpit of Prophet 
Muhammed (s.a.w) in Madinah, he explicated his policy obviously and said: "Indeed, I shall never treat the troubles of this nation except by my sword...... I swear by God that I will kill whomsoever preaches me about being pious after this meeting" (Al-Siouti, 2004:165).

The tyranny of the Umayyad and Abbasids was accompanied by blood shedding. They both commanded their sons to follow their footsteps. Abdul Malik Ibn Marwan commanded his son, Al-Walid, saying: "when I die, then call the people to pay allegiance to you. Then, cut the throat of whomsoever refuses that" (Ibn-Kathir, 2003:82).

Many people followed this tyrannical track. Al-Siouti (2004:613) says: "The ruler ordered his subjects that on hearing his name mentioned by the orator on the pulpit, they had to spring to their feet in queues, as a sign of reverence to his person and respect to his name. The people of Egypt, specifically, used to prostrate on the ground after standing up. Moreover, people in markets and the like prostrated like them". The ruler was also a stubborn oppressor and a satanic vicious man, who was often deceitful in his sayings and actions.

The continuous culture of subjugation in the Arab society has exterminated the chance for positive thinking that can elevate the nation. According to Khatami (2001:244), thinkers and missionary preachers avoided thinking about the affair of life, and even considered that hateful, others resorted to superficiality when speaking about the Shari'a (Islamic law) to justify the existent despotism and the prevalent tyranny.

$\mathrm{i}$ - The mechanism of divine authorization: This means considering the ruler to be infallible and sacred. It moved to Muslims through Persians after they had mixed together, following the Islamic conquest, when they did translate the Persian culture.

With the rise of the Umayyad dynasty, the motto of divine authorization began to appear, as the nomadic nature of Arabs abhors servility and compliance, and it is also difficult for them to practise leadership without a religious show and manifestation. According to IbnKhaldun (n.d:75), Arabs are a nation extremely far from the policy of monarchy and they never take over monarchy without a religious manifestation, such as the status of prophecy, holiness, or a great religious prestige overall.

Hence, Umayyad and Abbasids depended on the theory of divine authorization in stabilizing their rule and despotism. According to Al-Abbadi (n.d:30), the Umayyad asserted that Allah had selected them for caliphate and bestowed monarchy upon them, and that they behaved according to His will and ruled based on His consent. They ascribed to Allah's messenger sayings or hadiths that support their standpoint, such as the hadith: "Sultan is Allah's shade on earth" (Al-Baihaqi, n.d:479). Again, Abdul Malik Ibn Marwan stood on the pulpit, giving a speech saying: "Oh people! We have become leaders over you and guardians of you. We lead you with the power that Allah had bestowed on us, and we protect you with the inspiration that Allah had granted us" (Safwat, 1996:273). The Umayyad considered whomsoever contradicted this maxim to be against Islamic law, and accused him of blasphemy (heresy), terrorism and belonging to a terrorist group.

To stabilize the principle of divine authorization and sacredness of the ruler in the Umayyad and Abbasid dynasties did what follows:

1) They announced among the people of Syria that they deserved the caliphate on account of being relatives to Allah's Messenger (s.a.w) (Al-Balazri, n.d:2-10). Whenever one of them acceded to the caliphate throne he wore the Messenger's Banjabi (Indian gown) that Mu'awiyah had taken from 'Aisyah, the wife of Allah's Messenger (s.a.w) (Ibn-Asakir, n.d:153). Al-Walid Ibn Abdul Malik denied that a caliph would be questioned for punishment in the afterlife (Al-Souti, 2004: 197). Then his brother Yazid Ibn Abdul Malik summoned forty Religious scholars who issued a Fatwa (legal opinion) saying that a caliph 
would not be questioned for punishment in the thereafter (Ibn-Kathir, 2003:13). On the day of 'Arafah (Hajj), Al-Mansour stood on the pulpit saying: "O people! Indeed, I am the deputy of Allah on his Earth" (Al-Siouti, 2004:229).

2) The Abbasids, like the Umayyads, called for the idea of the (Sacred Family), which meant that their caliphate was a religious legal succession passed from the household of the prophet. So, people cannot but be totally obedient. Under Abbasids rule, the tone of sacredness was elevated to that of deification. Ibn Hanie al-Andalusi, without any restriction, said to the Fatimid caliph, Al-Mu'iz li Dinillah: "it is your will, not that of the fate, that takes place. So, take over the power as you are the one and the subduer, as a God" (Ibn-Kathir, 2003, vol. 15, p. 341). According to the principle of divine authorization, there is no election. There is no worth for the so-called persons entrusted with administration, which the caliph selects, as a person being elected cannot have power over that which had chosen him (Imam, 1994:188)

ii- $\quad$ The mechanism of beliefs justifying tyranny: The Umayyad dynasty had sought to mislead Muslim by telling them that they have no choice in their deeds and they were free of the sins of these obligatory actions. Thus, Mu'awiyah Ibn Abi Sufyan and his successors wanted to convince people that their power and rule over Muslims must be admitted. So, they encouraged the belief in fatalism. Mu'awiyah wrote to Al-Mughirah Ibn Shu'bah: "write to me what you have heard from Allah's Messenger (s.a.w). Al-Mughirah wrote to him: "I heard Allah's Messenger (s.a.w) saying when concluding prayer: There is no god but Allah, no partner to Allah; He is the owner of the universe; He deserves praise, and He is omnipotent. O Allah! No one can prevent your gift! No one can give what you prevent! And it is no use seeking benefit except from you!"'” (Ahmad, n.d:169). Thus, he made people understand from that hadith that their rule is predestination by Allah, and it must be accepted.

There is a link that relates the methods of ruling in the early Islamic state and in the contemporary Arab world. It is the dependence on the mechanism of religious beliefs, in which the political atmosphere sought to make religious concepts conforming to despotism through adopting some beliefs. For the Umayyad were neither likeable nor were they sincere Muslims. Under Umayyad and Abbasid rules, each party gained the favour of politicians as long as they did not contradict despots and did justify their tyranny for them. Whomsoever did otherwise was punished with slaughter and torture (Al-Sayid, n.d:95).

The belief in determinism, which means that a slave of God has no choice or will in all what he does (Ibn-Batta, n.d:192), resulted in the notion that a caliph or king is not elected by the people. Rather, he is a fate predestined by Allah over his slaves. So, all people have to surrender to his rule whether he was pious or immoral. The Umayyad saw that the call for fatalism or predestination justifies all their unjust deeds. Then, they tried to explain every transgression as being Allah's ordainment and destiny (Mahmoud, 1955:197). The Umayyad assured their sacredness worthiness of the caliphate through the stream of fatalism notions. People believed Mu'awiyah was Allah's deputy on earth as he is the trusted and entrusted agent. The rulers are Muslims' Imams, and thus the subjects cannot but obey and yield to them (Al-Douri, 1986: 195).

The belief in deferral (irjal), which means that faith is mere saying without action (IbnBatta, n.d:893), resulted in the fact that they did not differentiate between the tyranny of the Umayyad and that of the Abbasids, or between the justice and mercy of Abu Bakr Al-Sidiq and those of Umar bin Khattab, may God be pleased with both. Then, even though tyrants and despots do whatever evils they wished, they will not be questioned after death. The tyrants 
will be indifferent about whatever tyrants he commits, as the important thing is to testify that there is no God but Allah. Then, they will be exempted from the rules of what is allowed and what is forbidden. It is not allowed to decide rulings about their deeds as Allah alone knows the truths of hearts.

iii- $\quad$ The mechanism of the cultured component of Persia: Mu'awiyah was keen on the manifestations of Persian life. Umar said about him: "this is Qisrah of the Arabs (Ibn-Kathir, 2003: 128). Since the early days of Umayyad dynasty, the movement of translation into the Persian language had taken place, and especially concerning monarchy ruling. The examples are Mirrors of rulers, Advice of Kings, and The Monarchy Ethics.

Thus, the Persian cultural component stabilized tyranny in the Umayyad state and formulated a system for it. It was considered the ideal manner for ruling. For the Persian compilations in its Islamic appearance become the predominant factor in the Islamic political manipulation across most of the history (Salim, n.d:56). The problem of the nation is that when they had translated the cultures of other nations, they skipped the democratic experience of these nations and did not transform or translate it.

Since the first days of the Abbasid caliphate, the influence of Persian thought and its men had an obvious existence in Islamic ruling, military, and policy. Al-Abbadi says: "The theory of office of caliph changed much during the era of the Abbasids and became extremely similar to the theory of divine claim or right that had previously prevailed among Persians during the Sassanid era. Allegiance was given in the name of the acceptable one among prophet Muhammed's household, considering that the prophet's household are the ones most entitled to power. The Persians felt affinity to them as Al-Hussain had married the daughter of Yazdager, the last King of the Sassanid Persians (Al-Abbadi, n.d:20-22). Depending on the Persian men and belief, the Abbasid caliphate had risen. As for belief, they were inspired with the theory of sacred divine claim or right from Persian during the rule of Akzarsis who ruled the dynasty of Sassanid. As for men, this caliphate depended on Persians, who hate the Umayyad and had party spirit to the Arab race, in the Islamic history. The Abbasids depended on Persia for everything. Thus, they kept their caliphate on the basis of superiority of men of religion in their state to show the difference between it and the Umayyad state. The Abbasids wished to prove for themselves the divine claim or right, in the form of a godly power with religious manifestations (Ibrahim, n.d:207).

The Abbasids did not accept to be only Kings. Rather, they wanted that people would recognize first that they were religious rulers and that their government was religious and had religious formalities. Thus, the Umayyad were replaced by a godly power with religious manifestations (Imam, 1994: 188).

In Persian culture, there must be a sacred family (household) that takes over religious affairs. Through their party spirit for the prophet's household, there was a revival of the beliefs of Zoroastrian, Mano, and Mazdak. They replaced al-Maghad household with the household of Allah's prophet, who are Allah's shade on Earth. In them, the divine wisdom is manifested (Al-Gharib, 1978: 30).

Hence, tyranny began to be maximized in the name of religion in the Islamic sphere "Since the Iranians began to be represented in the court of the Abbasid caliphate, especially during the era of al-Ma'mun and Harun al-Rashid. The Shahenshah (The greatest Persian King) was the ideal for the Abbasid epoch in formality and law (Khatami, n.d:245). The Abbasid rule remained despotic, with a religious character, they favoured and mixed with men of religion 
in order to gain from them the sacred nature and propagated this theory among people (Ibrahim, n.d: 208).

People of Persian descent (Samanians-Ghaznians) used to follow in their ruling manner in the court of the Abbasid dynasty in the footsteps of ancient Iranians. The Shahenshah the ideal image to be followed by the Abbasid policy. The law in the Abbasid caliphate, which granted legality to their rule was conforming to the system or regime of the Shahenshah. With the coming of Islam, this law became more stable or constant and comprehensive as it acquired the nature of the Quran, the prophetic tradition, and Islamic religious jurisprudents, rather than that of Zoroastrian religion (Khatami, 2001: 244-245).

\section{The position of Islamic missionary concerning the mechanisms of origination of tyranny in the Islamic State}

i- $\quad$ The missionary vocation's stand towards the mechanism of overpowering and subduing: In Islamic missionary, the opinion of a person under compulsion is not considered. As documented in Ghayah al-Amani, Imam Malik said to the people of Madinah: "I did take the pledge from you while you were forced and compelled, and a person under compulsion is not responsible for his oath" (Al-Alusi, 2001: 23). Also, in Islamic missionary, an overpowering ruler is considered to be corrupt deserving punishment and is not worth preaching at. He should not be commanded to do good to what he had dominated (overpowered). Rather, he deserves reproach and detestation, as well as stating publicly his terrible deeds and corrupt conduct. On account of his corrupt conduct and vicious deeds as well as his deviation or outrage, his accession to the office of Imam had not been truly actual in spite of the pledge and allegiance given him (Ibn-Hajar, n.d:627). According to Ghiyath alUmam, it is legal to grant the office of Islamic ruler to a profligate (immoral) man. And if his rebellion breaks out for a certain necessity, then this necessity is no longer found and the ruler still grasps power, trying to force people of influence to give him oath of allegiance, this will be a Kind of transgression and violation and a compulsion of influential figures to pay him pledge under obligation. This is unfair oppression that makes a ruler considered immoral [AlGouini, n.d:238). Hence, missionary commanded the society to aid their Imam (ruler) and fight those who revolt against him. Ibn al-Munzir says: "If an Imam or ruler received the office of caliph deservedly and all people offered him allegiance, then one who had paid him pledge voluntarily did revolt against the ruler, this rebel must be fought"

ii- $\quad$ The Missionary position on the theory of divine authorization: The Islamic missionary does not admit the theory of divine Authorization. Likewise, it did not admit the infallibility of the ruler whatever his status, except for prophets as they were supported with divine revelation. However, Allah's prophet s.a.w said publicly: "Whomsoever I had unjustly lashed con come and lash me likewise and retaliate by insulting me and offend my dignity" (AlTabarani, n.d:280). None of the rightly guided Caliphs Called for divine authorization. Rather, they ruled through a free allegiance paid by Muslims. Abu Bakr said: "I have been entitled as a ruler over you, but I am not the best of you. So, if I rule correctly, then support me, and if I rule wrongly, then correct me" (Addin,1400AH: 483). Umar Ibn al-Khattab also said: "whosoever seen a deviation in my behaviour should correct it" (Ibn-Abdullah,1979: 292). In an hadith, "a woman has spoken and Umar has spoken wrongly..." (Ibn-Kathir, n.d:573). Also following the oath of allegiance to Imam 'Ali bin Abi Talib, he said: "O people! Indeed, I am one of you! I have the same due rights as you the same duties as you!" . All these mean that the mechanism of divine authorization never occurred to the minds of rightly guided Caliphs. Therefore, Islamic missionary has asserted the principle of consultation (shura) and that it is 
the characteristic nature by which the Muslim community abides. Allah mentions consultation between two great pillars of Islam, prayer and Zakat. Allah says: "And those who obey their God's order and perform prayer, used consultation in their affairs and give out the poor dues deserved in the poor dues deserved in the wealth we granted them" (surah alShura, verse 38-39). Allah also commands his messenger (s.a.w) to use consultation when He says: "And consult others in your affairs", "And those who consult each other in their affairs..." (surah 42, verse 38). Rashid Rida (1990: 165) says: "consultation 'shura' is the ideal method for achieving justice. Islam had set up the bases of ruling upon consultation. An example is what happened in the battle of Uhud as consultation took place as to whether fighting should take place outside or inside the Madinah (yathrib). Although, the prophet desired that fighting should take place inside, the young men's opinion was to fight outside the prophet's city (Burhanuddin 1400AH: 491). Tyranny dominated the society when consultation vanished as a rejection of mechanism of divine authorization, the nation was the source of legality in the missionary preaching. According to Al-Sanhuri (1989: 94), Allah had made the Muslim nation the owner of disposal in their affairs if they use this power within the limits of Allah's book and prophet's tradition.

iii- $\quad$ The stand of missionary preaching on the mechanism of tyrannical beliefs: Islamic missionary preaching assures that Allah had granted man the ability to make choice and act without an external compulsion. That is because this is canonical religious objective as it is the criterion of afterlife examination reckoning by Allah. According to Imam al-Shatibi, the religious canonical objective of imposing shari'ah is to make a responsible person devoid of personal inclination thus, he will offer slavery to Allah by his will, in addition to his compulsory slavery to Allah (Al-Raisuni, n.d:137). Thus, determinism was never known or stated, even by reference, in Islamic vocation, neither in the Quran nor in the Sunnah. That is because this is a belief that leads to disbelief in and denial of commandments and warnings in the missionary call. Al-Zubaidi said: "Allah's commandment and power are so great that He will never compel or force people. Rather, He will ordain and predestinate fate, and create and build up his slve as He likes (Al-Ashkar, 2005: 79). Al-Zuhri said: "No innovation in Islam was devise, more harmful to Muslims than that of deferral (irjai) (Ibn-Batta, n.d:885). Also, Ibn Abdul Barr said: "scholars of jurisprudence and prophetic hadith unanimously said: that belief (faith) is saying, deed, and intention, and any deed is worth nothing without intention.

In the Quran, faith was stated as being coupled with good deeds, fifty times. Sufyan Ibn Abdillah al-Thakafi said: "I said: O Allah's messenger! Tell me a saying about Islam after which I need not ask anyone about it! Then he said: "say: I believe in Allah, then be righteous" (Muslim, n.d: 38). Muhammed Ibn Al-Hussein said: "Anyone's faith is never complete until it is believed by his heart, applied by his body organs, and uttered by his tongue, being so obvious to anyone who learnt the Quran by heart and read it" (Al-Ajari, n.d:616). Undoubtedly, the careless call for the notion of deferral had caused tyranny on the pretext assuming that belief is stable in the hearts of despots and that it never lessens or diminishes with their transgression.

iv- The missionary coll,s stand on the cultural component of Persian state: The Islamic missionary is a seal perfect vocation. Allah says: "We never left anything ignored in the book...". Also, Allah's Messenger (s.a.w) says: "All the perfect inspired sayings were revealed to me" (Ibn-Hanbal, n.d:366). So there was no need for Mu'awiyah to follow the Persian culture in ruling. It was only because this met his personal inclination and appealed to him subjectively. So Allah's Prophet (s.a.w) warned of this imitative subordination when he says "I swear by my Creator, I have been sent to you with a clear pure message. When asking your 
righteous guides, then never refute what they call right or believe in what they never refute what they call right or believe in what they call false. I swear by my Creator, were prophet Moses ('a.s) to be alive, he would certainly follow me" (Ibn-Hanbal, n.d:387).

The cultural component of the Islamic vocation in the ruling system is based on election, choice and offering allegiance according to the principle of consultation (shura) stated in the Qur'an, the sunnah, and the practice of the rightly guided caliphs. All what has been done across time, and since the Umayyad dynasty until now, have no relation with the rightly guided caliphate and its Islamic systems. It "rather sprang from the rigid conception of the rightly guided Caliphate" (Al-Fayyumi, 2003: 131). The hateful openness to the Persian cultural components and subordination to it evolved from a vacancy or emptiness in the Arab soul as its conception then was "a superficial childish conception" (Al-Ghazali, n.d:6). This subordination had done harm to Islam and its history. It even deformed the originality and superiority of Islamic missionary which has its authentic method in ruling "according to the conception of the Qur'an, the Prophetic tradition, and the practice of rightly guided caliphs" (Al-Gendi, 1978: 139). Muslims have to abide by the methodology of Islamic vocation call and stop following the cultural components of other nations that contradict Islamic teachings.

\section{Conclusion}

The paper has concluded many results, the most important of which is that: the system of Islamic caliphate was not responsible for the tyranny of rulers. Rather, the responsibility falls on their breaking and violation of the principles and objectives of Islamic ruling. Tyrants are indifferent to people's acceptance and consent obedience and complete yielding. Rulers in the Arab world are superior to law, they are not questioned about what they do. Tyranny in the Arab world is a restriction of thought and of scholar, as well as accusing. The real cause is politics. Tyranny causes destruction of human moral values and the prevalence of hypocrisy and flattery. The material deeds (actions) of tyrants are valueless if they destroyed the dignity of man. Religious beliefs that revived in the beginning of the Islamic state ensued up on political happenings or events. Tyranny is the cause of backwardness of the Arab world and the immigration of geniuses abroad.

The study recommends conducting contemporary studies uncovering the mechanisms of despotism which are renewable in the Arab world. Conducting psychological missionary studies for combatting despotism in the Arab society. Setting up societal centres and international conference that enlighten society about the consequences of tyranny. Conducting studies that highlight the role of Islamic missionary in achieving justice and human dignity for all. Conducting studies for refuting the illusions of tyranny and despotism.

\section{References}

Al-Alusi, A. M. S. (2001). Ghayat al-Amani fi al-Rad 'ala al-Nabahani, Abu Abdullah al-Dani Ibn Munir (ed.). N.p: Maktabah al-Rushd, It edition.

al-Hadid, I. A. (n.d) Sharh nahj al-Balaghah, Mohamed Abul Fadl Ibrahim (ed.). Cairo: Dar Ihya' al-Kutub al-'Arabi, Isa al-Babi al-Halabi.

Al-Agorri, B. (1999). Al-Shariah. Abdullah Ibn Omar al-Demereigi. Dar al-Watan, $2^{\text {nd }}$ edition.

Al-Ashkar, O. (2005). Al-Qada' Wa al-Qadar. Dar al-Nafais for Publishing and distribution, $13^{\text {th }}$ edition.

Imam, F. A. (n.d) A tyrant: A philosophical study of some of examples of despotism. The series of Alam al-Marifah, 183. 
Al-Blazeri, I. Y. (1996). Jumal min ansab al-Ashraf, Sohail Zakkar and Ryiad al-Zarkali (eds). Dar al-Fikr, $1^{\text {st }}$ edition.

Addin, B. (1400AH). Al-Sira al-Halbiah fi sirat al-Amin al-Mamon. Beirut: Dar al-Ma'arif.

Al-Guaini, A. M. I. A. (1979). Giyath al-Umom wa al-Tiath al-Zulam. Fuad Abdul Mun'im Dar al-Da'wah.

Al-Gendi, A. (1978). Shubuhat at-Tajrib fi al-Ghazw al-Kufari. Beirut: Al-Maktab al-Islami.

Ibn-Hajar, A. A. (1997). Al-Sawaiq al-Muhriqah 'ala ahli al-Rafdi wa al-Dalal wa al-Zandaqah. Abdul Rahman al-Turki and Kamil al-Kharrat (eds.). Mu'assasah al-Risalah, $1^{\text {st }}$ edition.

Khatimi, M. (2001). Al-Din wa al-Fikr wa al-Istibdad. Maktabah al-Shuruq. $1^{\text {st }}$ editon.

Ibn-Khaldun. (n.d). The introduction or preface. Authar source $\&$ the book: al-Warrak site.

Al-Duri, A. A. (1986). Democracy and human rights in the Arab homeland. The centre for studies of Arab unity.

Al-Zahabi, S. (1985). Siyar a'lam al-Nubalaa. A group of researchers under the supervision of Sheikh Shu'aib al-Aranaot. Mu'assasah al-Risalah, $3^{\text {rd }}$ edition.

Al-Raisuni, K. A. (1992). Nazariyat al-Maqasid 'ind al-Imam al-Shatibi. Al-Dar al-Alamiyah li alKitab al-Islami, $2^{\text {nd }}$ edition.

Zeidan, K. A. (1993). Al-Sunan al-Ilahiyyah fi al-Umam wa al-Jama'ah wa al-Afrad fi al-Shari'ah al-Islamiyyah. Mu'assasah al-Risalah, I $^{\text {st }}$ edition.

Al-Suyuti, J. A. R. (2004). Tarikh al-Khulafaa. Hamdil al-Damardash (ed.). Maktabah Nizar alBaz, $1^{\text {st }}$ edition.

Al-Sayyid, S. M. (1985). Amr Ibn Ubaid wa 'ara'ahu al-kalamiyah. Cairo: Nahdah al-Shuruq, Cairo university.

Al-Sanhuri, R. A. (1989). Fiqh al-Khilafah. Nadia al-Sanhuri (trans.). Tawfiq al-Shadi (rev.). AlHa'iah al-Masriyyah li al-Kitab.

Safwat, A. (n.d). Jamhara Khutab al-'Arab fi al-'Usur al-Arabiyyah al-Zahirah. Al-Maktabah al'Ilmiyyah.

Al-Aqqad, A. (2012). 'Abqariyyah al-Imam 'Ali. Cairo: Mu'assasah Hindawi.

Al-Abbadi, A. (n.d) Mukhtar fi al-Tarikh al-Abbasi wa al-Fatimid. Dar al-Nahdah al-'Arabiyyah. Sakirullah, A., \& Mohd, H. (2019). Civil Marriage In The Light Of Fiqh Al-Maqaasid, Nigeria As A Case Study. International Journal Of Academic Research In Business And Social Sciences, 9(4).

Wahab, N., \& Ismail, M. S. (2020). Fiqh Muamalat Islam: Hukum Dalam Sistem Jual Beli Atas Talian (E-Dagang) Dari Sudut Pandangan Fuqaha [Islamic Muamalat Of Fiqh: Legal System In Selling Online (E-Commerce) From The Fuqaha Islamic View]. AL-QIYAM International Social Science and Humanities Journal, 2(1), 24-35.

Mokhtar, W. K. A. W., Ibrahim, A., \& Embong, A. H. (2018). Al-'Aqīdaț Al-Șaḥịhaț as the Essential Element of Worldview of Development Integrity and Accountability. International Journal Of Academic Research In Business And Social Sciences, 8(11), 328-337.

Al-Ghazali, M. (n.d), Al-Ghazw al-Thaqafi yamtadu min firaghina. Dar al-Shuruq.

Al-Fayumi, I. M. (2003). Al-Khawarij wa al-Murji'ah. Dar al-Fikr al-'Arabi, $1^{\text {st }}$ edition. Ibn-Kathir. (2003). Al-Bidayah wa al-Nihayah. Abdullah al-Turhi (ed.). Dar Hajar. Mahmud, A. (1955). Falsafah al-Tafkir fi al-Islam. Cairo: Maktabah al-Anglo. 